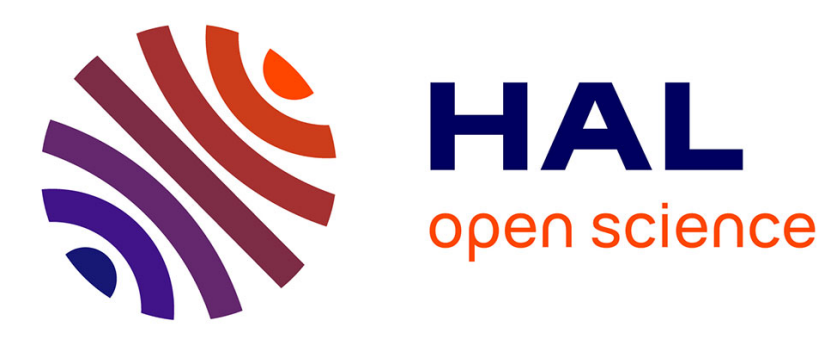

\title{
On Punishment and Well-being
}

Jordi Brandts, María Fernanda Rivas

\section{To cite this version:}

Jordi Brandts, María Fernanda Rivas. On Punishment and Well-being. Journal of Economic Behavior and Organization, 2009, 72 (3), pp.823. 10.1016/j.jebo.2009.08.001 . hal-00723633

\section{HAL Id: hal-00723633 \\ https://hal.science/hal-00723633}

Submitted on 12 Aug 2012

HAL is a multi-disciplinary open access archive for the deposit and dissemination of scientific research documents, whether they are published or not. The documents may come from teaching and research institutions in France or abroad, or from public or private research centers.
L'archive ouverte pluridisciplinaire HAL, est destinée au dépôt et à la diffusion de documents scientifiques de niveau recherche, publiés ou non, émanant des établissements d'enseignement et de recherche français ou étrangers, des laboratoires publics ou privés. 


\section{Accepted Manuscript}

Title: On Punishment and Well-being

Authors: Jordi Brandts, María Fernanda Rivas

PII: $\quad$ S0167-2681(09)00196-6

DOI: $\quad$ doi:10.1016/j.jebo.2009.08.001

Reference: $\quad$ JEBO 2433

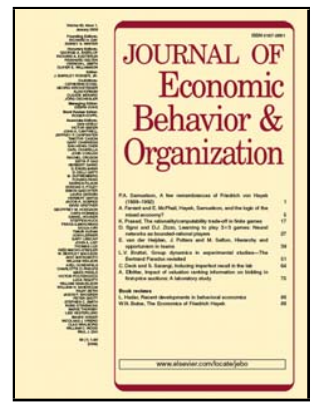

To appear in: Journal of Economic Behavior \& Organization

Received date: $\quad$ 21-12-2007

Revised date: $\quad 31-7-2009$

Accepted date: $\quad$ 4-8-2009

Please cite this article as: Brandts, J., Rivas, M.F., On Punishment and Well-being, Journal of Economic Behavior and Organization (2008), doi:10.1016/j.jebo.2009.08.001

This is a PDF file of an unedited manuscript that has been accepted for publication. As a service to our customers we are providing this early version of the manuscript. The manuscript will undergo copyediting, typesetting, and review of the resulting proof before it is published in its final form. Please note that during the production process errors may be discovered which could affect the content, and all legal disclaimers that apply to the journal pertain. 


\title{
On Punishment and Well-being
}

\author{
Jordi Brandts*and María Fernanda Rivas ${ }^{\ddagger}$
}

July 30, 2009

\begin{abstract}
The existence of punishment opportunities has been shown to cause efficiency in some public goods experiments to increase considerably. In this paper we ask whether punishment also has a downside in terms of process dissatisfaction. We conduct an experiment to study the conjecture that an environment with strong punishment possibilities may lead to higher material payoffs but lower subjective well-being, in comparison with weaker punishment or no punishment possibilities at all. The more general motivation for our study stems from the notion that people's subjective well-being may be affected by the institutional environment they find themselves in. Our findings show that harsher punishment possibilities lead to significantly higher well-being, controlling for earnings and other relevant variables. These results complement the evidence on the neural basis of altruistic punishment reported in de Quervain et al. (2004).
\end{abstract}

JEL Classification Numbers: C92, D60, H40

Keywords: Public Goods, Experiments, Well-being, Punishment

\footnotetext{
*Department of Business Economics, Universitat Autònoma de Barcelona and Institut d'Anàlisi Econòmica (CSIC), Barcelona.

${ }^{\dagger}$ GLOBE, Department of Economics, Universidad de Granada.

${ }^{\ddagger}$ The authors thank the Spanish Ministry of Science and Innovation, the Barcelona GSE Research Network and Consolider-Ingenio 2010 (CSD2006-00016) for financial support.
} 


\section{Introduction}

As is well-known many situations of social interaction can be envisioned as public-good-type games in which individuals have incentives to "free-ride" on others' contributions to the public good and spend their own resources on other individually higher-valued uses. A large stream of experimental papers has documented that people often contribute to the public good and sometimes with large amounts of money. Nevertheless, observed inefficiency levels are still large and increase with experience, often ending up at near-zero provision.

However, in many such environments with free-riding incentives, people do not need to passively accept the free-riding of others. There often exist punishment opportunities of some sort, the possibility of taking actions that impose costs on others. Experimentalists have studied whether this possibility has any effect on social interaction, particularly when punishing others is costly. In an early contribution, Ostrom et al. (1992) study behavior in a repeated common pool resource game with uncertain horizon under different conditions involving punishment, communication and non-binding agreements. They find that under some conditions punishment opportunities lead to lower withdrawal levels from a common pool resource. ${ }^{1}$ However, the fact that in their design the duration of the interaction is uncertain makes it possible that participants treat the environment as one of infinitely repeated interaction so that there are material incentives for cooperation and punishment.

Fehr and Gächter (2000) report results from a finitely repeated public good experiment with and without costly punishment opportunities in which cooperation and punishment can never be part of subgame-perfect equilibrium, if rationality and selfishness are common knowledge. They provide very convincing evidence that the existence of punishment opportunities leads to a large increase in contributions. In one interesting extension Masclet et al. (2003) used experimental methods to study the power of informal non-material sanctions in a public good game and found that monetary and non-monetary sanctions initially increase contributions by a similar amount. Over time, however, monetary sanctions lead to higher contributions than non-monetary ones.

We take this evidence on the effectiveness of punishment as our starting point. If one simply stopped questioning at this point, social environments with strong punishment possibilities would appear preferable to environments that lack such possibilities. However, we believe that to make a judgement about the desirability of effective punishment possibilities one more element needs

\footnotetext{
${ }^{1}$ It should be noted here that in their sanctioning-only setting withdrawal levels become more efficient, but earnings are decreased when fines and fees are included.
} 
to be taken into consideration: the effect of punishment on process satisfaction. The general motivation for our study is the notion that people's subjective well-being may be affected by the institutional environment they find themselves in and that economists need to understand these relations. Rabin (1993, p. 1283) formulates this as follows: "Welfare economics should be concerned not only with the efficient allocation of material goods, but also with designing institutions such that people are happy about the way they interact with others... Armed with well-founded psychological assumptions, economists can start to address the nonmaterial benefits and costs of the free market and other institutions."

What led us to conducting the experiments presented in this study is the suspicion that the presence of punishment possibilities might have a downside, i.e. the possibility of using sanctions that impose a material cost may lead to low subjective well-being due to an uneasiness about the environment in which participants are immersed. If this were true, then it would not be straightforward to make an overall welfare judgement on the goodness of the presence of punishment possibilities, since two counter-vailing forces would have to be somehow compared with each other. If, in contrast, the presence of punishment possibilities had no significant or even a positive effect, then the judgement on the different institutional arrangements would be more direct, since both factors would point in the same direction.

We use the notion subjective well-being similarly to Kahneman, Wakker and Sarin's (1997) notion of "experienced utility", which goes back to Bentham. These authors consider that subjective well-being (or experienced utility) is both measurable and empirically distinct from standard decision utility. A subjective view of utility recognizes that everybody has his own ideas about happiness and the good life and that observed behavior is an incomplete indicator for individual well-being. Applied to our environment, it may well be that people make use of punishment possibilities and even that this leads to higher material payoffs. However, from here one can not directly conclude that people experience higher subjective well-being in such an environment.

We measure subjective well-being through self-assesments of participants' satisfaction with the experience in the experiment. Our focus is on the comparison of subjective well-being across different treatments in which we vary the punishment possibilities, going from no punishment, to soft punishment and strong punishment. In making this comparison we control for possible determinants of subjective well-being other than process considerations.

The novel aspect of this paper is precisely the analysis of the effects of punishment on 
subjective well-being. We believe that understanding this relation is important for a better understanding of social interactions. Our work is related to the study by de Quervain et al. (2004) on the neural basis of altruistic punishment. In that study subjects' brains were scanned while they learned about the defector's abuse of trust and determined the punishment. It was found that the fact of effectively punishing a defector produces a satisfactory impact on the brain. What we study is not the direct effect of punishing on the punisher, but the effect on individuals of one of the features of the environment in which they interact.

In the next section we present some background material on the measurement of well-being and on issues related to process satisfaction. After that we present the experimental design and procedures and then the results. Our main results show that strong punishment possibilities lead to significantly higher well-being than the other two environments, controlling for income and other relevant variables.

\section{Background and previous evidence}

Kahneman, Diener and Schwartz (1999) provide a wealth of information about the importance of well-being. Recent overviews about research into happiness and well-being and its relation to economics are provided among others by Frey and Stutzer (2002), Krueger (2005), and McFadden (2005). Veenhoven (1993) - the author is the founder of the Journal of Happiness Studiespresents a study on happiness all over the world.

Van Praag and Ferrer-i-Carbonell (2004) present the perhaps most exhaustive study of what the authors call satisfaction analysis, based on the responses to subjective questions of the following type: How satisfied are you with your financial situation, job, health, life, etc. Please respond on a scale from "very bad" to "very good" or on a numerical scale from 1 to 7 or 1 to 10.

The authors of this study assert that humans often evaluate many aspects of their situations guided by the objective of changing their life. They argue that "the empirical practice and success of these questions constitute ample evidence that individuals are able and willing to express their satisfaction on a cardinal scale. If we assume those questions to be interpreted in approximately the same way by different respondents and we find that similar respondents give similar answers, this is ample evidence that (approximate) interpersonal comparison is possible." They discuss how to study financial, job, housing, health, leisure, and environment satisfaction 
- what they call domain satisfactions - as well as satisfaction with life as a whole as a weighted aggregate of the domain satisfactions. The methodology is then applied to job satisfaction for a British data set and to political satisfaction for a Dutch survey. ${ }^{2}$

There are a few experimental papers studying issues of well-being. Charness and Grosskopf (2001) analyze the relation between the importance people attach to relative payoffs and happiness, motivated by the conjecture that those who are less happy may seek solace in obtaining higher material payoffs than others. The experiment consisted in subjects making choices in simple dictator-type (one-shot) decisions tasks and in filling out a happiness questionnaire. The results summary is that there is no strong general correlation between happiness and concern for relative payoffs, but that the willingness to lower another person's payoff below one's own (competitive preferences) seems correlated with unhappiness.

Brandts et al. (2004) study the impact of competition on the well-being of experimental subjects. Their approach is somewhat different from that of Charness and Grosskopf (2001). The idea is not to measure people's homegrown levels of happiness but to evaluate whether different experiences in the lab could lead to different levels of process satisfaction. The paper studies the effects of competition on well-being in a setting where one player can choose to interact in a dilemma game with one of two other players. The results show that competition has an adverse effect on the disposition towards others of the two players who compete for the interaction with the first player, controlling for earnings and other relevant variables.

Note, and this will become clearer below, that it would have been difficult to carry out this kind of studies on the basis of field data alone, since in natural environments it would be very hard to find adequate data with the desired parallel variations in the punishment conditions. It would probably have been even harder to obtain the corresponding information about subjective well-being.

\footnotetext{
${ }^{2}$ For other research papers studying happiness see Easterlin (2001), Blanchflower and Oswald (2000), Di Tella et al. (2001), Diener and Oishi (2000) and Diener and Seligman (2004). Frey and Stutzer (2002) present an extensive survey of the literature on happiness.
} 


\section{Experimental design and procedures}

In our experiments subjects interacted in pairs in a 20-round public goods game; the finite horizon was common information. ${ }^{3}$ After the 20 rounds they had to answer one simple question about process satisfaction. There were two treatment variables: the punishing possibilities and the type of matching. The first distinction responds to what motivates our study, while the second distinction will allow us to compare our work to that of Fehr and Gächter (2000). We studied three different cases of punishment possibilities: one where punishment was not possible at all and two with punishment possibilities which differed with respect to the "fine-to-fee" ratio, which describes by how much the punished subject's income is reduced relative to the fee the punishing subject has to pay to inflict punishment. We studied both strangers and partners matchings. Table 1 summarizes our $3 \times 2$ treatment design and shows the numbers of participants in each cell.

Table 1: Treatments and Number of Participants.

In the sessions, subjects were coupled randomly by the computer, maintaining the anonymity of the interaction partner. ${ }^{4}$ Each treatment was run in one session. In the strangers treatments pairs were changed from round to round while in the partners treatments the groups were constant across rounds. The experiment was conducted at the Universitat Autònoma de Barcelona with undergraduate students of a variety of faculties. Participants were recruited by public advertisements posted throughout the campus.

The first stage of each round was the same for all six treatments. The four treatments with punishment possibilities have also a second stage. In the two treatments with punishment possibilities each round had two stages. In the first stage each participant was asked to divide 5 tokens between two accounts, a group account — called account A in the experiment - and a private account - account B. Tokens placed in account A yield an identical amount of money to both members of a pair. Tokens in account B yield money only to the subject in question. Table

\footnotetext{
${ }^{3}$ Using pairs is the simplest starting point for studying what we are interested in. Group size effects could be studied in subsequent work. The two-person setting is different from those of previous studies in the sense that subjects that are sanctioned know which other subject sancioned them. This can be particularly relevant in the partners matching case.

${ }^{4}$ The experiment was programmed and conducted with the software z-Tree (Fischbacher, 2007). Appendix 1 contains the instructions for the partners with strong punishment treatment.
} 
1 gives the payoff schedule, in tokens, depending on the contributions to account $\mathrm{A}$, where $\mathrm{X}$ is the contribution of the subject in question and $\mathrm{Y}$ is the contribution of his partner. The first value of the cells is his payoff and the second one his partner's payoff. Apart from these payoffs participants received 3 euros for showing up. The payoffs were calculated with a marginal per capita return of investment in the public good (henceforth, MPCR) of 0.75 , to create sufficient tension between the Nash equilibrium and the Pareto efficient allocation.

Table 2: Payoffs for the Public Good Game.

The first stage of each round was the same for all six treatments. After the first stage of each round participants saw on their screens their partner's decision and both payoffs calculated following table 2. In the four punishment treatments there was a second stage in which participants had the opportunity to punish their partners at a certain cost, inflicting either a strong or a soft punishment. ${ }^{5}$ The complete punishment schedules for the two types of punishment can be seen in table 3. The amount of money that could potentially be spent on punishment is constant across the two treatments. What varied was the fine-to-fee ratio which was 4 under strong punishment and 1.6 under soft punishment.

Table 3: Punishment cost schedules

After the subjects had decided on the punishment level, they saw on their screens the first part payoffs, the punishment their partner decided to inflict on them, the cost of deducting tokens from their partner's payoffs and their final payoffs - for the current period - calculated as: Final earning = Initial payoff (from table 2) - Tokens deducted by the partner - Cost of deducting tokens from the partner's payoff (from table 3). Then the first part of the new round began and things proceeded in the same way until the end of round 20. After the 20 rounds participants saw on their screens a summary of the experiment: contributions, punishment, and payoffs for each period.

After the interaction part of the experiment was over, we obtained our measurement of subjetive well-being. Then we distributed a questionnaire (see appendix 2). In the questionnaire

\footnotetext{
${ }^{5}$ In the instructions it said: "Then, each participant will have the opportunity of showing his approval/disapproval about his/her partner's contribution by choosing a number of tokens to be deducted from his/her partner's earnings with a certain cost." This language is more leading than the neutral language used by Fehr and Gächter (2000). Sefton et al. (2007) use the term 'sanctioning' when describing alternatives to participants, which can also be considered to be less neutral language.
} 
subjects were asked to indicate to what extent they agreed - on a six degree scale - with some statements, some of them referring to the punishment and others referring to their answer to the question about the satisfaction with the experiment. After they had filled out the questionnaire subjects were privately paid. Their final payoff was the total number of tokens earned (the sum for all the periods) converted into euros ( 1 token $=0.10$ euros) plus the show-up fee (3 euros).

\section{Results}

The main focus of our work is on the results on subjective well-being which will be presented in section 4.1. Before that we present some results on public goods contributions, punishment behavior and earnings which will allow us to relate our work to that of others and to better understand the results on well-being. Much of this presentation will be kept at a descriptive level. Table 4 shows some preliminary information. One can see that the Kruskal-Wallis tests indicate that the data from the three punishment treatments do come from different distributions.

Table 4: Average values of the main variables

We now study the behavior of the three variables shown in table 4 more in detail. Figure 1 shows the average individual contributions per period for the six different treatments.

Figure 1: Contributions to the group account by type of punishment and matching

The data presented in the figure confirms the impression obtained from inspecting the averages in table 4 . The main difference is due to the type of matching rather than the type of punishment

In figure 2 we show the percentage of subjects that punished the partner by period for each one of the four treatments. ${ }^{6}$ Under strangers matching, the percentage is higher for strong punishment than for soft punishment, in 18 out of the 20 periods (in the other 2 periods the percentages are the same). For partners, in the first 12 periods the percentages are quite similar, but in the last 8 periods the percentage of subjects that punished the partner is higher for soft

\footnotetext{
${ }^{6}$ Naturally, the figure does not include any data from the treatment without punishment.
} 
punishment than for strong punishment. ${ }^{7}$

Figure 2: Percentage of subjects that punished their partner by type of Punishment and Matching.

Figure 3 shows a histogram of punishment in terms of the punishment levels of table 3 for the four treatments. The key feature is that punishment is not used very much, with the frequency of a zero level punishment being between $66 \%$ and $85 \%$, depending on the treatment.

Figure 3: Histogram of punishment levels

To further understand the punishment process we want to relate the use of punishment not only to the treatment variables but also to behavior in the previous period, in particular to the difference between a participant's own contribution and the contribution of the partner. Given the high frequency of zeros in the levels of punishment, we decided to estimate a probit model where the dependent variable is a dummy that has value 1 if the subject punished his partner - regardless of with which amount - and has value 0 if the subject did not punish. To account for multiple observations in the estimation we clustered on subjects.

In table 5 we present the marginal effects resulting from the ordered probit estimates. The first two variables refer to the treatments. The next two variables represent the deviations negative or positive - of the partner's contribution from the subject's one. They are equal to:

$$
\begin{aligned}
& \text { Negative deviation }=\operatorname{Max}\{0, \text { my contribution }- \text { my partner's contribution }\} \\
& \text { Positive deviation }=\operatorname{Max}\{0, \text { my partner's contribution }- \text { my contribution }\}
\end{aligned}
$$

The results show that the possibility of punishing strongly and a negative deviation have a strongly significant positive effect on the probability of punishing the partner; a Tobit estimation yields similar results. Partners matching has a positive effect, significant at the $10 \%$ level. What is perhaps more surprising is that the variable positive deviation is statistically significant and has a positive sign. It can be interpreted as evidence of spiteful preferences on the part of some

\footnotetext{
${ }^{7}$ The overall percentages were $55 \%, 62 \%, 91 \%$ and $79 \%$ for soft punishment/strangers, soft punishment/partners, strong punishment/strangers and strong punishment/partners, respectively. The p-values of the tests that compare means are 0.004 (t-test) and 0.005 (Mann-Whitney U test) for the total. For strangers the p-values are both 0.007 , and for partners they are 0.178 and 0.179 .
} 
players. ${ }^{8}$ However, the effect of a negative deviation is more than 3.5 times as large as that of a positive deviation, and the effect is found to be significant only at the $10 \%$ level. $^{9}$

Table 5: Estimations of the punishment behavior

The subjects were paid - as mentioned before - for the sum of earnings in the 20 periods - converted into euros - plus the show-up fee of 3 euros. In table 6 we show the average final earnings without the show-up fee. The average earnings are statistically different under strangers than under partners, but the difference between strong and soft punishment is not statistically significant. ${ }^{10}$ Comparing earnings across the punishment conditions, we do find differences between the no punishment treatment and the other two, but not between soft and strong punishment. ${ }^{11}$

Table 6: Average final earnings (in euros)

\subsection{Well-being}

This section presents the data about the main focus of the paper, namely, the relation between subjective well-being and the type of punishment the subjects are playing under. In section 4.1.1 we show some descriptive statistics about the distribution of the well-being variable and its relation to the types of punishment, matching and to other variables. In section 4.1 .2 we present the results of ordered probit models, in which we estimate the effect of the punishment environment, controlling for relevant variables.

\footnotetext{
${ }^{8}$ According to Falk et al. (2005) "Spiteful sanctions are those that occur because the sanctioning subject values the payoff of the sanctioned subject negatively, regardless of whether the sanctioned subject behaved fairly or not".

${ }^{9}$ Fehr and Gächter (2000) found also that a subject is more heavily punished the more his contribution falls below the average contribution of other group members - they have groups of 4 subjects. Masclet et al. (2003) found the same pattern of punishment. They also found that subjects that contributed low amounts were using the punishment more number of times than other subjects.

${ }^{10}$ The p-value of the t-test and the Mann-Whitney $U$ test is 0.000 for the overall comparison of partners vs. strangers as well as for the comparison within the strong punishment and the no punishment cases. However, the difference is not significant for the soft punishment case.

${ }^{11}$ The p-value of the t-test and the Mann-Whitney U test are 0.550 and 0.087 for soft vs. strong, 0.210 and 0.042 for soft vs. no punishment and 0.048 and 0.006 for strong vs.no punishment.
} 


\subsubsection{Some descriptive statistics}

As mentioned above, we measure subjective well-being through self-assessments of participants' satisfaction with the experience in the experiment. The question is: How satisfied would you say that you are with the experiment? The possible answers were : 1) Completely dissatisfied, 2) Very dissatisfied, 3) Rather dissatisfied, 4) Neither satisfied nor dissatisfied, 5) Rather satisfied, 6) Very satisfied, 7) Completely satisfied. ${ }^{12}$ The frequencies of answers to the question about well-being for all six treatments can be seen in figure 4 . Figure 4 shows that nobody chose level 1 (Completely dissatisfied) as an answer, and that people have a tendency to locate in the middle of the distribution.

Figure 4: Distribution of the well-being variable for all six treatments

Figure 5 shows the answers to the well-being question by type of punishment.

Figure 5: Distribution of the well-being variable by type of punishment

Comparing the distributions for soft and for strong punishment one can see that the second is to the right of the first one. ${ }^{13}$ However, the comparison with the no punishment distribution is less clear-cut, although it appears to be more in line with the strong punishment distribution than with the one for soft punishment. ${ }^{14}$

The next step is to ask what other variables can explain the well-being of subjects. ${ }^{15}$ The variable Final Earnings in figure 6 has, as could be expected, a positive impact on the well-being of subjects, which is quite similar across the three punishment conditions.

Figure 6: Relation between well-being and final earnings

\footnotetext{
${ }^{12}$ Our well-being question is similar to one of the questions asked by Charness and Grosskopf (2001) in their more extensive happiness questionnaires.

${ }^{13}$ If one takes each observation to be independent, then these averages can be said to be statistically different. The p-value of the t-test and Mann-Whitney $U$ test are 0.081 and 0.061 , respectively.

${ }^{14}$ Neither the t-tests nor the Mann-Whitney U tests yield significant results.

${ }^{15}$ We gathered some independent information about these other variables. After the experiment we had subjects fill out a questionnaire, where we asked if they agreed or disagreed with some statements, some of them referring to their answer about the satisfaction with the experiment. The results of this questionnaire show that $52.1 \%$ of the subjects were influenced by their profit when aswering the well-being question, where we counted the subjects that said that "Strongly agree" or "Agree". 66\% said that their partner contribution to account A was influencing their answer, and $31.9 \%$ said that the received punishment was influencing.
} 
In figure 7 we can see the relation between the different values taken by the well-being variable (except for completely dissatisfied that nobody chose) and the average values of the variables: average own contribution, average partner contribution and $\mathrm{Nb}$ of times subject contributed more than partner. The latest captures the number of times a subject contributed more tokens to account A than his partner, regardless of the intensity of the difference.

Figure 7: Relation between well-being and contributions

The higher the number of times the subject contributed more than his partner, the worse his well-being. On the other hand, the higher his own and his partner contribution, the better in well-being terms. We next describe the relation between well-being and punishment received. The variable $N b$ times subject was punished represents the number of times a subject was punished by his partner. We prefer it to the average punishment received because the effective punishment subjects could impose was different depending on the treatment and, in our estimation below, we wanted to estimate one equation including both treatments, moreover, both variables follow a similar pattern and have similar relation with the dependent variable, as can be seen in figure 8 .

Figure 8: Relation between well-being and punishment received

\subsubsection{Estimation of the well-being equation}

Table 7 shows the results of our estimations. In relation with the goodness-of-fit of the models, it can be said that the null hypothesis that models (II) to (VI) did not have greater explanatory power than an "intercept only" model, is rejected.

Table 7: Results of the ordered probit estimation

Focusing first on model (VI) we can see that strong punishment has a strongly significant positive effect on well being, while soft punishment does not have a significant effect (the no punishment case is the baseline). Our initial conjecture turns out to be incorrect. A strong punishment regime leads to subjects experiencing higher and not lower well-being.

The results for the other independent variables give further insights. Partners matching is not statistically significant, once one controls for final earnings, which are - as we know from 
before - higher under partners matching. ${ }^{16}$ Subjects do not derive any separate satisfaction from interacting always with the same person. The remaining variables are all significant and have the intuitive sign. Final earnings has the expected positive sign - material payoffs are an important positive determinant of subjective well-being. Often contributing more than the partner leads to a significant negative impact on well-being - people dislike to frequently be the sucker. Finally people dislike being punished and like to punish - recall here that the probability of punishment depends strongly positively on a negative deviation from the partner's contribution. ${ }^{17}$

The marginal effects shown in table 8 reflect increases in probability of being at one of the six well-being levels due to a change in each of the exogenous variables. With respect to the strong and soft punishment variables the figures in the table correspond to the effects of the switch from being in the no punishment environment to being in either the soft or the strong punishment environments. The table shows that switching to the strong punishment environment makes being in each of the three higher well-being levels significantly more likely, while it makes it significantly less likely to be at any of the lower well-being levels.

For the final earnings variable, the figures in table 8 correspond to the effect of taking the average individual and increasing that person's earnings by one token. ${ }^{18}$ One can see that for each level of well-being the marginal effect of the strong punishment dummy is larger than the one for final earnings and for all levels except $\mathrm{WB}=5$ it is more than twice as large as the one for the final earnings variable. However, in interpreting this one has to take into account the rather small monetary value of an increase in one token. Indeed, a meaningful change in earnings like $10 \%$ would affect well-being much more than the type of punishment

Table 8: Marginal effects of the ordered probit model

\footnotetext{
${ }^{16}$ We also estimated models including an interactive effect between the type of matching and the type of punishment, and found that the effect is not significant.

${ }^{17}$ We also estimated ordered probit models in which we included dummy variables for being punished after contributing less than the partner and for being punished after contributing more than the partner. The first of these variables has a significant effect on well-being, while the second does not.

${ }^{18}$ The marginal effects are valued in the mean of the variables.
} 


\section{Conclusions}

We set out to find a downside to the possibility of using punishment to deter free-riding. Instead, we find that people derive process satisfaction from interacting in an environment with harsher punishment possibilities compared to weaker and no punishment possibilities. It turns out that in our environment average earnings do not differ much between the strong and the soft punishment treatments. However, earnings are higher in the absence of punishment. When correcting for this income difference, well-being is higher under strong punishment than in the other two cases so that, in our case, the "superiority" of the strong punishment setting stems mostly from process satisfaction considerations. In a context like in Fehr and Gächter (2000) where strong punishment possibilities led to higher monetary earnings, both effects would go in the same direction.

Our results bear some relation to the study on the neural basis of altruistic punishment by de Quervain et al. (2004), in which subjects' brains were scanned while they learned about the defector's abuse of trust and determined the punishment. It was found that a punishment that reduced the defector's economic payoff activated the dorsal striatum which has been implicated in the processing of rewards that accrue as a result of goal-directed actions. The authors' interpretation of these results is that people derive satisfaction from punishing norm violations and that the activation in the dorsal striatum reflects the anticipated satisfaction from punishing defectors.

The results of the work we present in this paper can be seen as an independent confirmation of the general notion that people derive satisfaction from punishing. The participants in our experiments do derive well-being from the very act of punishing but also from being in an environment involving harsher punishment possibilities. Our well-being measure captures the satisfaction derived from the circumstances around the decision-making itself. Note that our result arises in a context in which punishment is sometimes used in a spiteful or at least somewhat unreasonable way; recall that we found that subjects punished their interaction partners for contributing more than themselves. This means that the results we find emerge despite the possibly detrimental effects of such sanctions — see Fehr and Rockenbach (2003).

We believe that our results are of relevance for some very basic issues about the organization of society. In a stable society, social norms guide the interaction among members of society under different circumstances. An important characteristic of organized society is its ability to restrict 
opportunistic behavior through the use of rewards and punishment. In this way social norms can often support high levels of cooperation among the members of a society. ${ }^{19}$ Our results show that, in addition to the material benefits that derive from the possibility of punishing people who do not comply with social norms, people obtain additional satisfaction from interacting under the "protection" of strong punishment possibilities. Gürerk et al. (2006) show that a sanctioning institution is the undisputed winner in a vote-with-your-feet type competition with a sanction-free institution. They find that in their experiments the entire population migrates successfully to the sanctioning institution and strongly cooperate, whereas the sanction-free society disappears. Our results suggest that this migration is not only motivated by material payoffs but also by the process-satisfaction of interacting in the sanctioning institution.

A final question is how to find an explanation for the effect we found. Intuition suggests some rather natural ex-post explanations. For example, one could say that people feel better when strong punishment opportunities are available, because they feel "secure"; they feel that the system works. However, to delve deeper into explaining our results one would need additional data. One possibility would be to use some kind of feelings and emotions questionnaire, but perhaps the more fundamental approach to finding an explanation would consist in designing a neural study that would be able to pick up the effect of an environmental variable like the one we have studied. Such a study might detect a satisfactory effect on the brain of being in a strong punishment environment.

\section{References}

[1] Blanchflower, D.G., Oswald, A.J.,2000. Well-being over time in Britain and the USA. NBER Working paper $N^{\circ} 7487$. Cambridge: National Bureau of Economic Research.

[2] Brandts, J., Riedl, A., van Winden, F., 2004. Competition and well-being. An experimental investigation into rivalry, social disposition, and subjective well-being. Available at http://www.iae.csic.es/brandts/index.htm, revised 2008.

[3] Charness, G., Grosskopf, B., 2001. Relative payoffs and happiness: An experimental study. Journal of Economic Behavior and Organization 45, 301-328.

\footnotetext{
${ }^{19}$ Dal Bó (2007)
} 
[4] Dal Bó, P., 2007. Social norms, cooperation and inequality. Economic Theory 30, 89-105.

[5] De Quervain, D.J.-F., Fischbacher, U., Treyer, V., Schellhammer, M., Schnyder, U., Buck, A., Fehr, E., 2004. The neural basis of altruistic punishment. Science 305, 1254-1258.

[6] Di Tella, R., MacCulloch, R.J., Oswald, A.J., 2001. Preferences over inflation and unemployment: Evidence from surveys of happiness. American Economic Review 91, 335-341.

[7] Diener, E., Oishi S., 2000. Money and happiness: income and subjective well-being across nations. In: Diener, E., Suh, E. (Eds.) Culture and subjective well-being. Cambridge, Massachusetts: MIT Press, 185-218.

[8] Diener, E., Seligman, M.E.P., 2004. Beyond Money. Toward an economy of well-being. Psychological science in the public interest 5.

[9] Easterlin, R., 2001. Income and happiness: Toward a unified theory. Economic Journal 111, 465-484.

[10] Falk, A., Fehr, E., Fischbacher, U., 2005. Driving forces of informal sanctions. Econometrica $73,2017-2030$

[11] Fehr, E., Gächter, S., 2000. Cooperation and punishment in public goods experiments. American Economic Review 90, 980-994.

[12] Fehr, E., Rockenbach, B., 2003. Detrimental effects of sanctions on human altruism. Nature 422, 137-140.

[13] Fischbacher, U., 2007. Z-tree. Zurich toolbox for readymade economic experiments. Experimental Economics 10, 171-178.

[14] Frey, B., Stutzer, A., 2002. What can economists learn from happiness research? Journal of Economic Literature 40, 402-435.

[15] Gürerk, Ö., Irlenbusch, B., Rockenbach, B., 2006. The Competitive advantage of sanctioning institutions. Science 7, 108-111

[16] Kahneman, D., Diener, E., Schwarz, N., 1999. Well-being : The foundations of hedonic psychology New York: Russell Sage Foundation. 
[17] Kahneman, D., Wakker, P.P., Sarin, R., 1997. Back to Bentham? Explorations of experienced utility. The Quarterly Journal of Economics 112, 375-405.

[18] Krueger, A. B., 2005. Well-being and policy evaluation. Presentation at the Econometric Society World Congress 2005, London .

[19] Masclet, D., Noussair, C.N., Tucker, S.J., Villeval, M.C., 2003. Monetary and non-monetary punishment in the voluntary contributions mechanism. American Economic Review 93, 366380 .

[20] McFadden, D., 2005. The new science of pleasure. Frisch Lecture, Econometric Society World Congress 2005, London, August 20, 2005.

[21] Ostrom, E., Walker, J., Gardner, R., 1992. Covenants with and without a sword: self governance is possible. The American Political Science Review 86, 404-417.

[22] Sefton, M., Shupp, R., Walker, J., 2007. The effects of rewards and sanctions in provision of public goods, Economic Inquiry 45, 671-690.

[23] Rabin M., 1993. Incorporating fairness into game theory and economics. American Economic Review 83, 1281-1302..

[24] Van Praag, B., Ferrer-i-Carbonell, A., 2004. Happiness quantified. A satisfaction calculus approach. Oxford: Oxford University Press.

[25] Veenhoven, R., 1993. Happiness in nations: Subjective appreciation of life in 56 nations 1946-1992. RISBO, Studies in Sociale en Culturele Verandering 2, 364. Erasmus University Rotterdam 


\section{Appendix 1: Instructions: Partners Matching, Strong Pun- ishment Treatment}

Thank you for coming to this experiment on decision making. You will be paid 3 euros for showing up plus the money you earn during the experiment which will depend on your and other participants' decisions. At the end of today's session you will be privately paid.

From now on the communication with other participants is not allowed. If you have any doubt during the reading of these instructions or at any moment of the experiment, rise your hand and you will be personally attended.

The experiment consists of two stages.

\section{First stage}

The first stage consists of 20 rounds during which you will be randomly paired with another participant, and nobody will know with whom he is playing. During the 20 rounds your partner will be the same participant.

In each round you will be credited with 5 tokens that you will have to decide how to divide (in integers) between two accounts: account A and account B. The tokens allocated to account B will go directly to your earnings, but the tokens allocated to account A will affect your earnings as well as your partner's.

For each token allocated to account A you will receive 0.75 tokens. Your partner will receive the same amount for each token you allocate to account B. In a similar manner, you will receive 0.75 tokens for each token your partner allocates to account A.

The tokens allocated to account B will affect only your earnings, your partner will not receive anything for them, as you will receive nothing for the tokens your partner allocates to his account B.

Therefore, your earnings will be the number of tokens that you allocate to your account B plus the returns from your and your partner's tokens allocated to account A, i.e. Your Earnings $=$ amount of tokens allocated to account $\mathrm{B}+0.75 *$ total tokens allocated by you and your partner to account A.

The possible earnings are represented in table A2, depending on your contribution $(\mathrm{X})$ and your partner's contribution $(\mathrm{Y})$ to account $\mathrm{A}$ - the contributions to account $\mathrm{B}$ is 5 minus the contribution to account A. The numbers in the cells represent your earnings (first value) and 
your partner's earnings (second value). These earnings include the tokens assigned to account $\mathrm{B}$ plus the returns from the tokens assigned to account A by you and your partner.

Table A2: Earnings depending on contributions $(\mathrm{X} \backslash \mathrm{Y})$ to account $\mathrm{A}$

For example:

- if you allocate 3 tokens to account $\mathrm{A}$ and 2 tokens to your account B, and your partner assigns 1 token to account $\mathrm{A}$ and 4 tokens to his account B, your earnings will be 5 tokens $(2+(3+1) * 0.75=5)$ and your partner's earnings will be 7 tokens $(4+(3+1) * 0.75=7)$. This is represented in the cell corresponding to $\mathrm{X}=3$ and $\mathrm{Y}=1$.

- if you allocate 2 tokens to account $\mathrm{A}$ and 3 tokens to your account B, and your partner assigns 2 tokens to account $\mathrm{A}$ and 3 tokens to his account $\mathrm{B}$, your earnings will be 6 tokens $(3+(2+2) * 0.75=6)$ and your partner's earnings will be 6 tokens $(3+(2+2) * 0.75=6)$. This is represented in the cell corresponding to $\mathrm{X}=1$ and $\mathrm{Y}=2$.

- if you allocate 1 token to account $\mathrm{A}$ and 4 tokens to your account B, and your partner assigns 4 tokens to account $\mathrm{A}$ and 1 token to his account B, your earnings will be 7.75 tokens $(4+(1+4) * 0.75=7.75)$ and your partner's earnings will be 4.75 tokens $(1+$ $(1+4) * 0.75=4.75)$. This is represented in the cell corresponding to $\mathrm{X}=1$ and $\mathrm{Y}=4$.

After every participant has chosen how much to assign to each account, you will be informed about the decision of your partner, and your and your partner's earnings. Then, each participant will have the opportunity of showing his approval/disapproval about his partner's contribution choosing a number of tokens to be deducted from his partner's earnings with certain cost. In table A3 you have the cost (in tokens).

\section{Table A3}

That means that, for example, to deduct 0.50 tokens from your partner's earnings would cost you 0.125 tokens, to deduct 1 token from your partner's earnings would cost you 0.25 tokens, to deduct 1.50 tokens from your partner's earnings would cost you 0.375 tokens, to deduct 2 tokens from your partner's tokens would cost you 0.50 tokens, to deduct 2.50 tokens would cost you 0.625 tokens, etc. 
After this step, the earnings will be again calculated, and they will be equal to:

Final earnings = Initial earnings (from table A2) - Tokens deducted by your partner - Cost of deducting tokens from your partner's earnings (from table A3)

Once the 20 rounds are over we will add up the tokens you have earned in all the rounds and we will calculate the total earnings in euros that will be $=$ total earned tokens $* 0.10$, i.e. each token is worth 0.10 euros. Therefore, your final payment will be: (Total tokens * 0.10) euros + 3 euros.

\section{Second stage}

In this stage a question will be asked. After that, we will pay.

\section{Appendix 2 : Post-experimental questionnaire}

Could you tell me if you completely agree, agree, disagree, or you completely disagree with the following sentences? (Mark with a cross your answers)

1) If it were cheaper to punish people, they would use more the punishment to show their discontent with the contribution of their partner to account A.

\section{Table A4}

2) If you knew that it is very likely that you will be punished, you would contribute more tokens to account A.

3) In your decision of how much to contribute to account A, what you thought your partner would do was very important.

4) The fact of being able to punish the partner makes both players contribute more tokens to account A.

5) The fact that both contributed more tokens to account A makes both feel more satisfied.

6) Your answer to the question about satisfaction with the experiment was influenced by how much you had earned (euros).

7) Your answer to the question about satisfaction with the experiment was influenced by how much your partner had contributed to account A. 
8) Your answer to the question about satisfaction with the experiment was influenced by how much punishment you had received.

9) Your answer to the question about satisfaction with the experiment was influenced by how much punishment you had inflicted to your partner.

10) Your answer to the question about satisfaction with the experiment was not influenced by any of the above mentioned facts.

11) If you partner had contributed more to account A you would have earned more and therefore you would be more satisfied because of your higher earnings.

12) If your partner had contributed more to account A you would be more satisfied given that he would have collaborated with you and not that much because of the higher earnings.

13) If in society there existed a stronger punishment system, people would obey more the rules and everybody would live happier.

14) If we lived in a more permissive society everybody would be happier. 
Figure 1: Contributions to the group account by type of punishment and matching

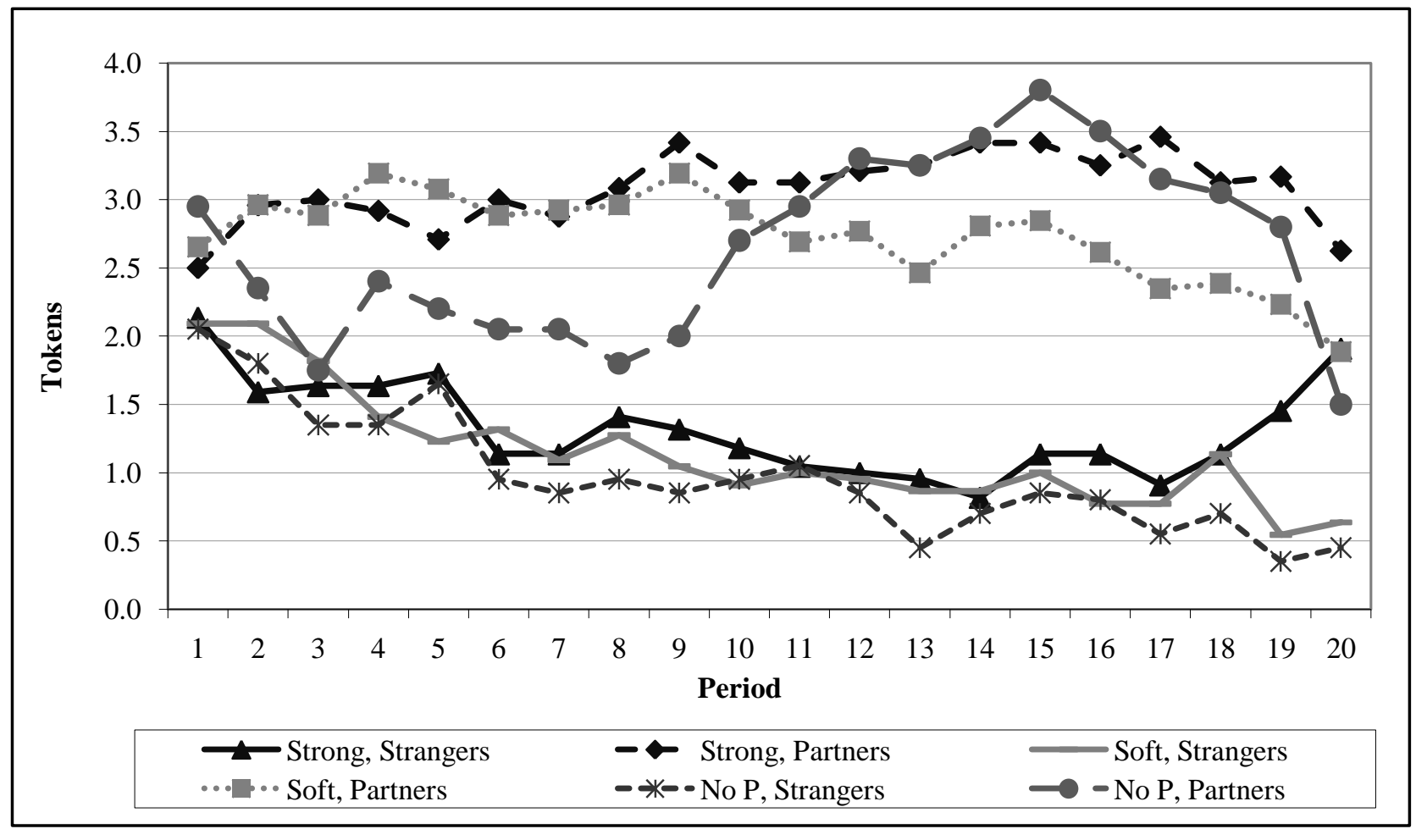


Figure 2: Percentage of subjects that punished their partner by type of punishment and matching

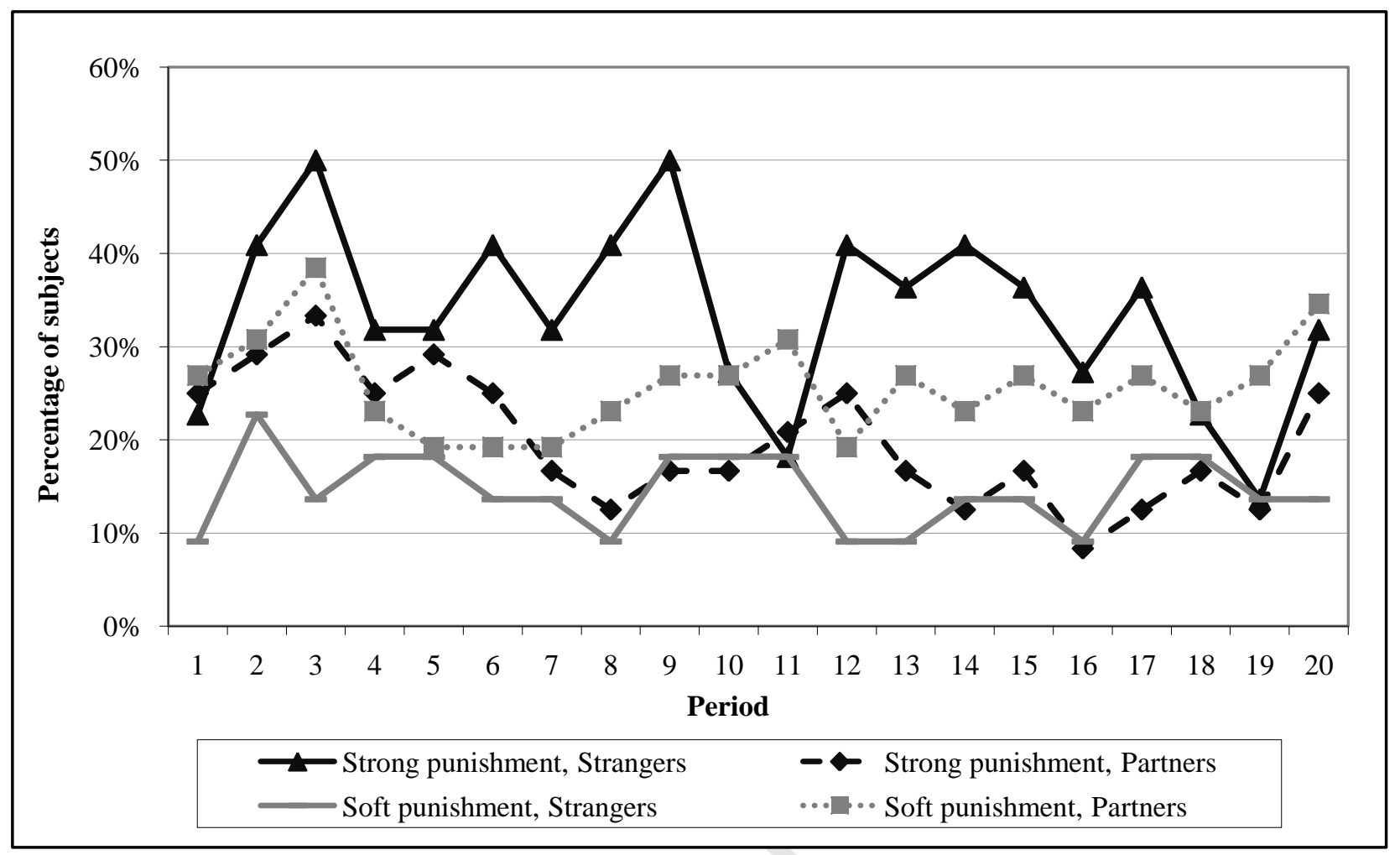


Figure 3: Histogram of punishment levels

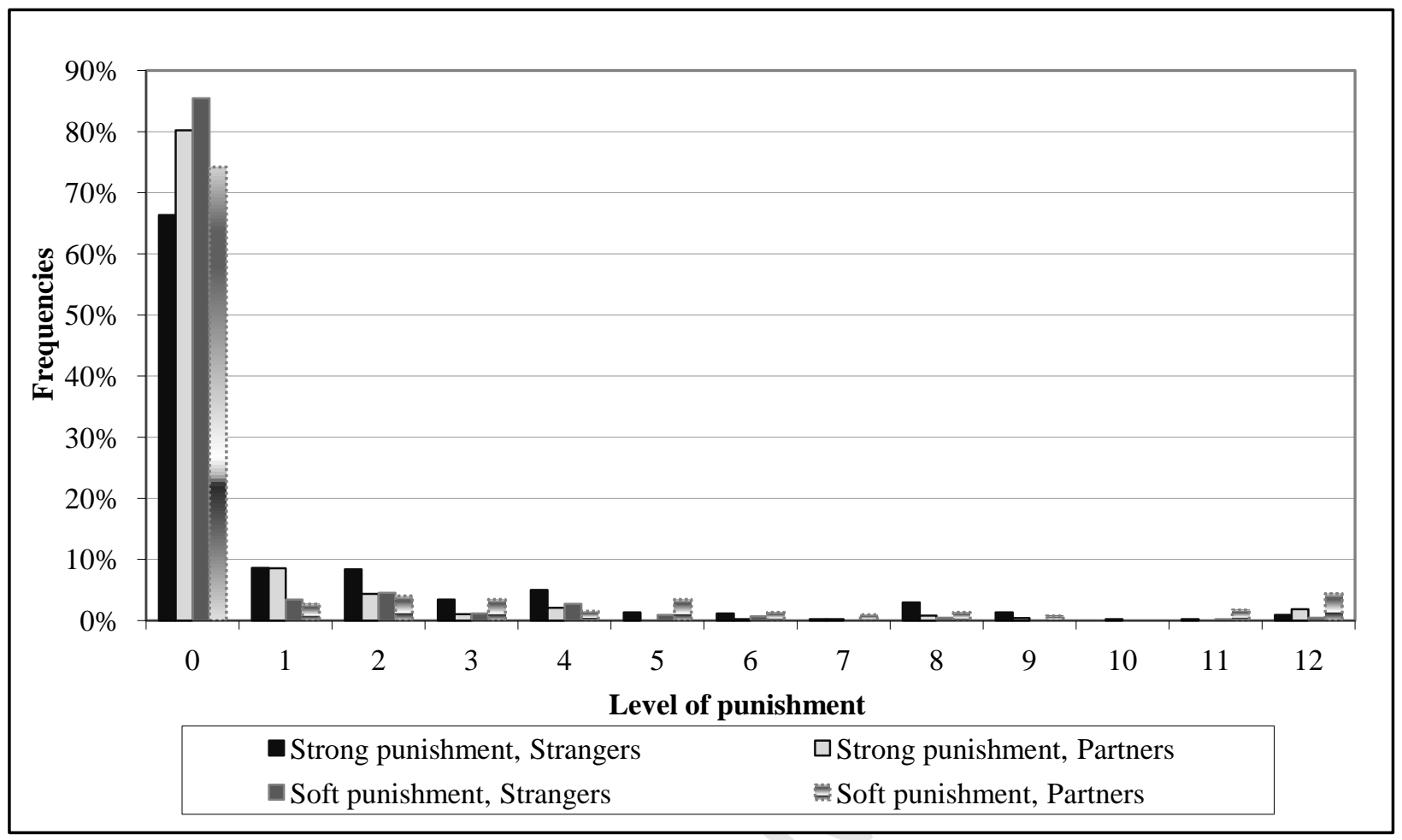


Figure 4: Distribution of the well-being variable for all six treatments

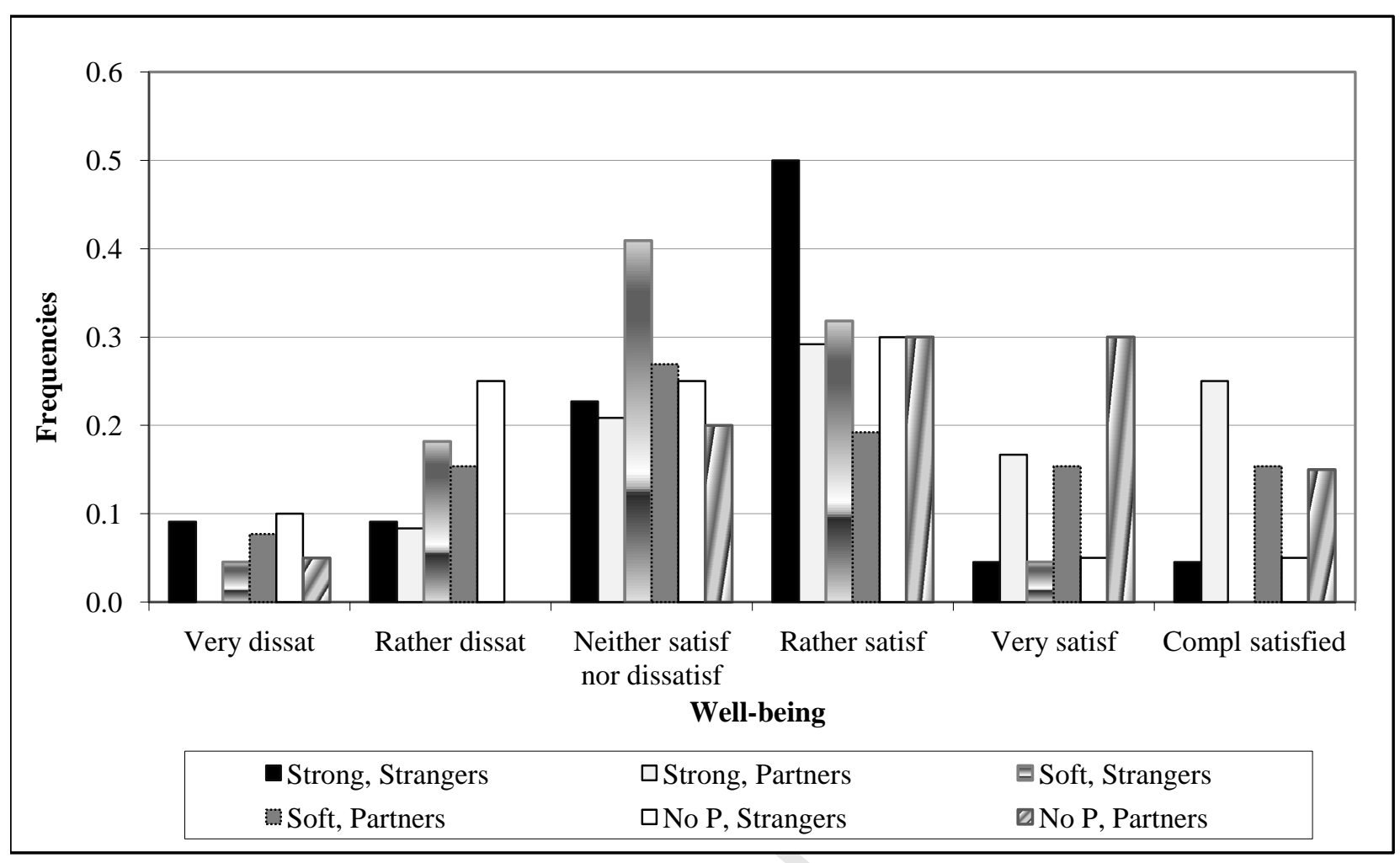


Figure 5: Distribution of the well-being variable by type of Punishment

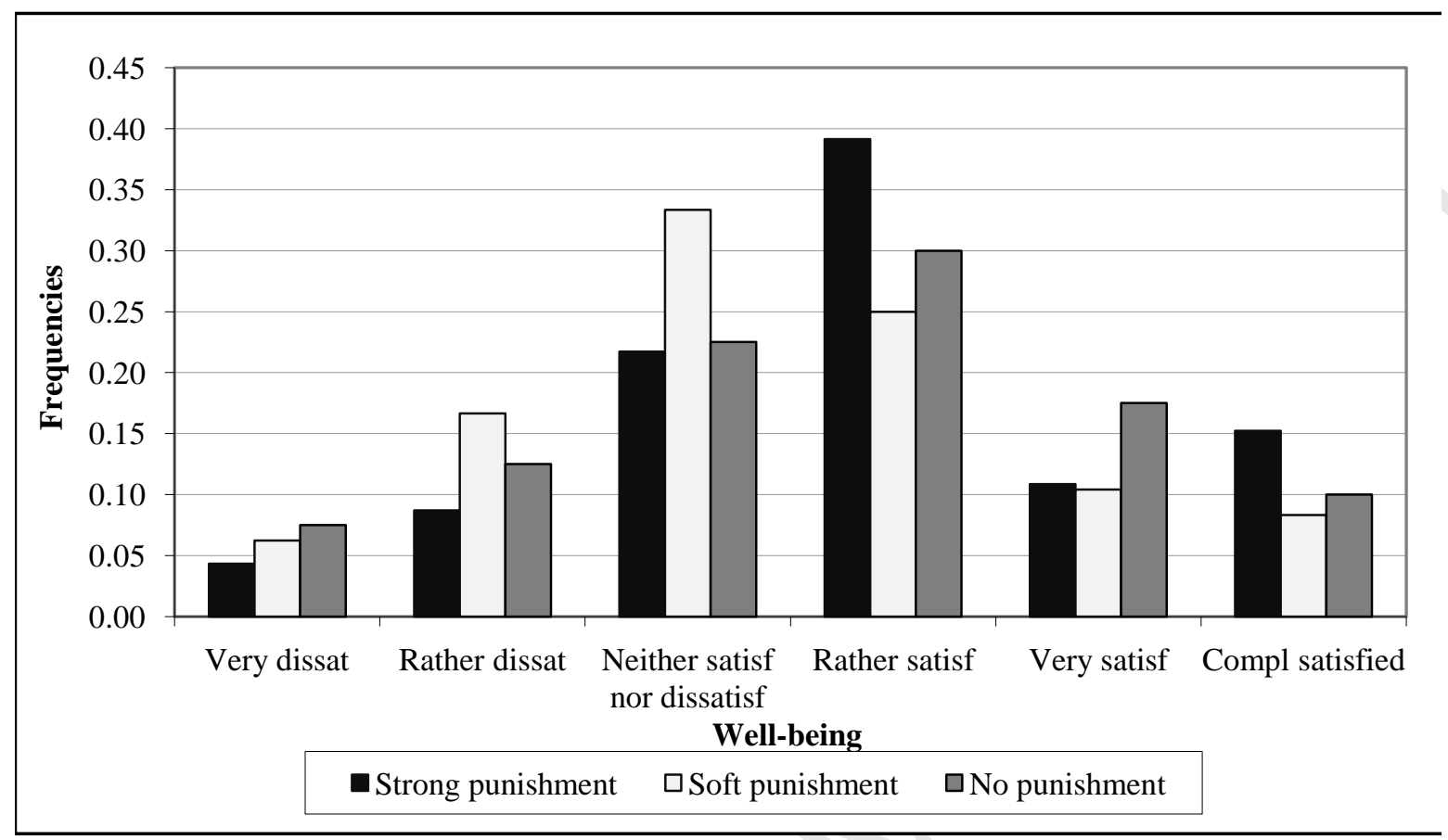


Figure 6: Relation between well-being and final earnings

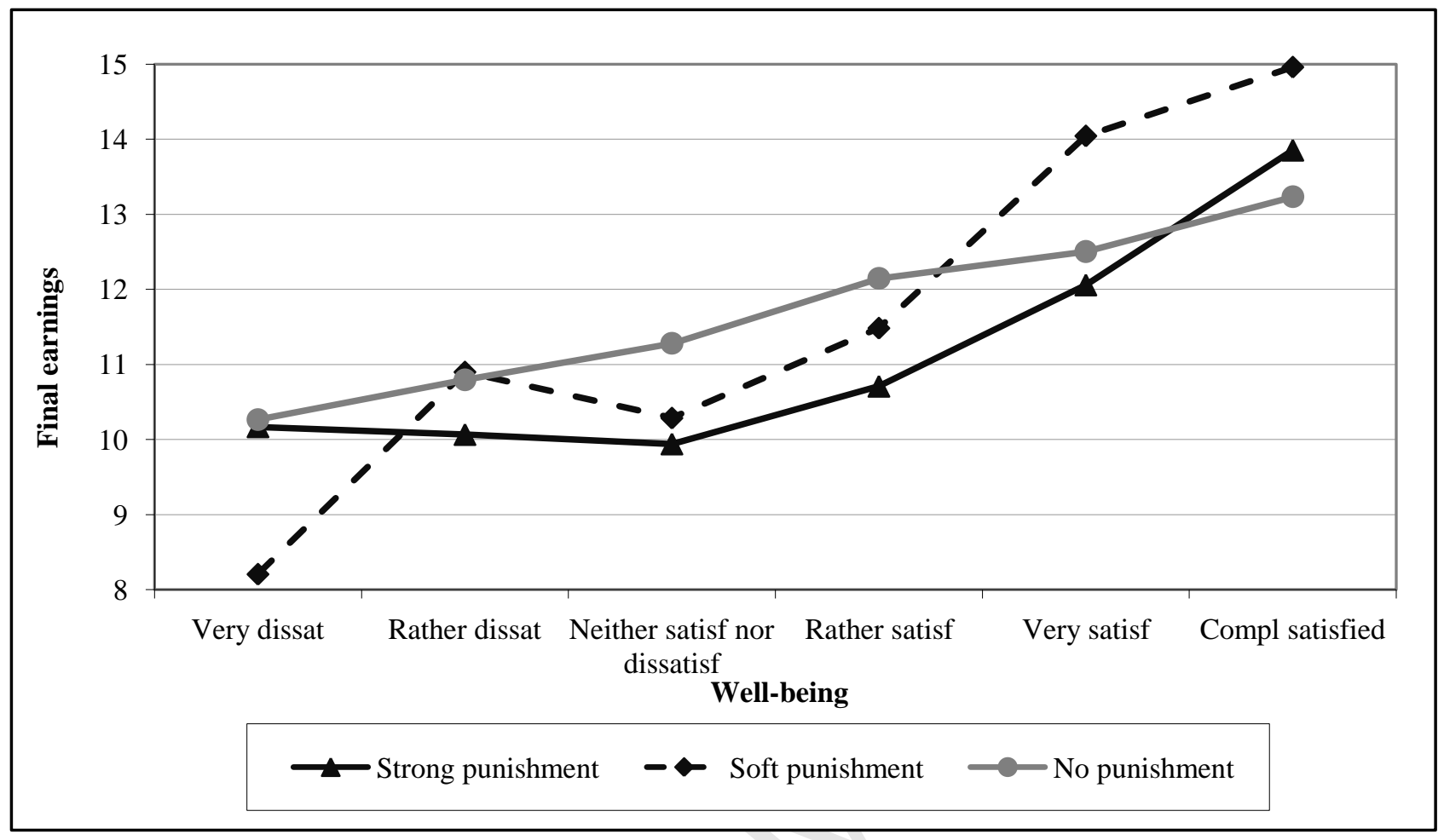


Figure 7: Relation between well-being and contributions

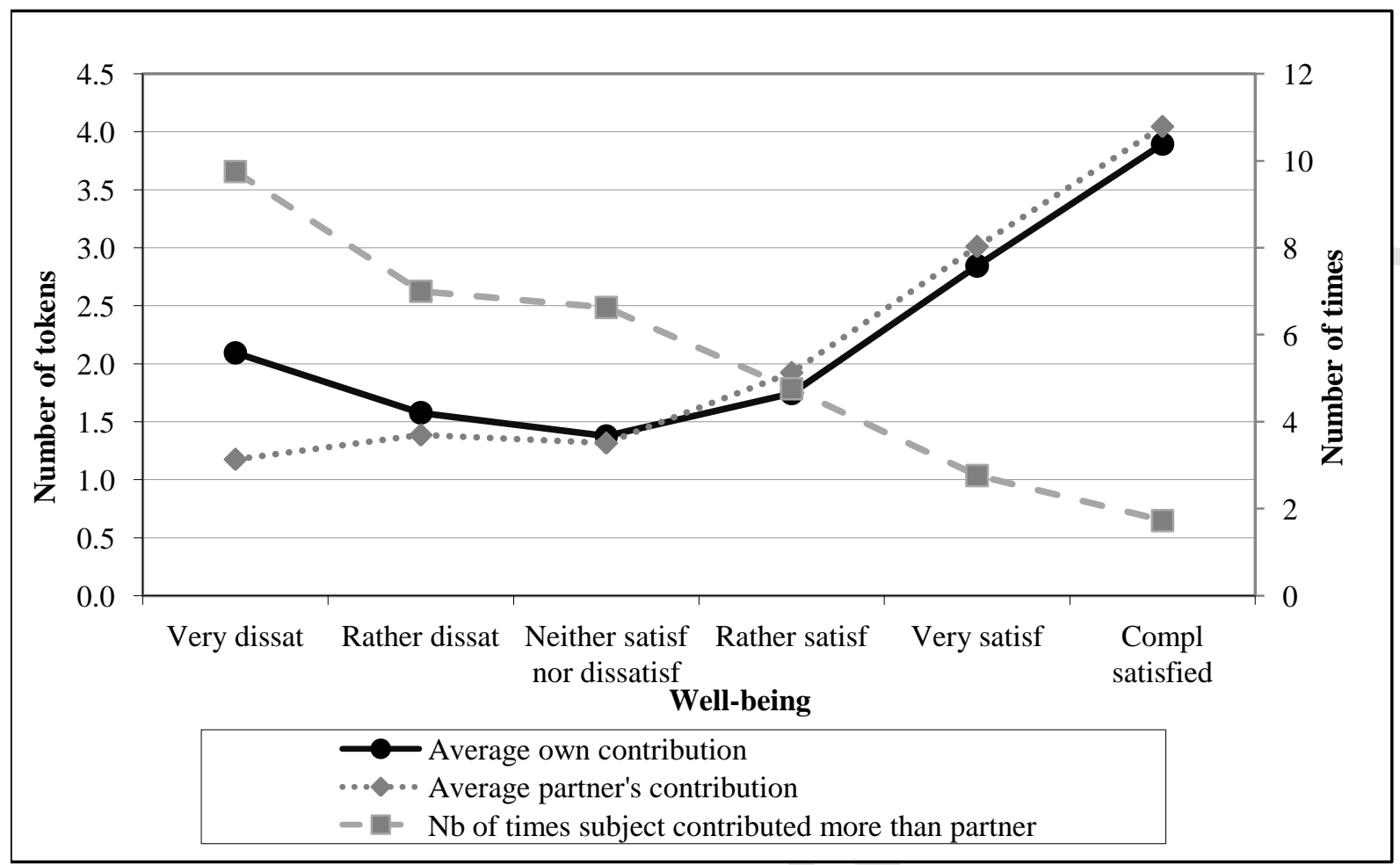


Figure 8: Relation between well-being and punishment received

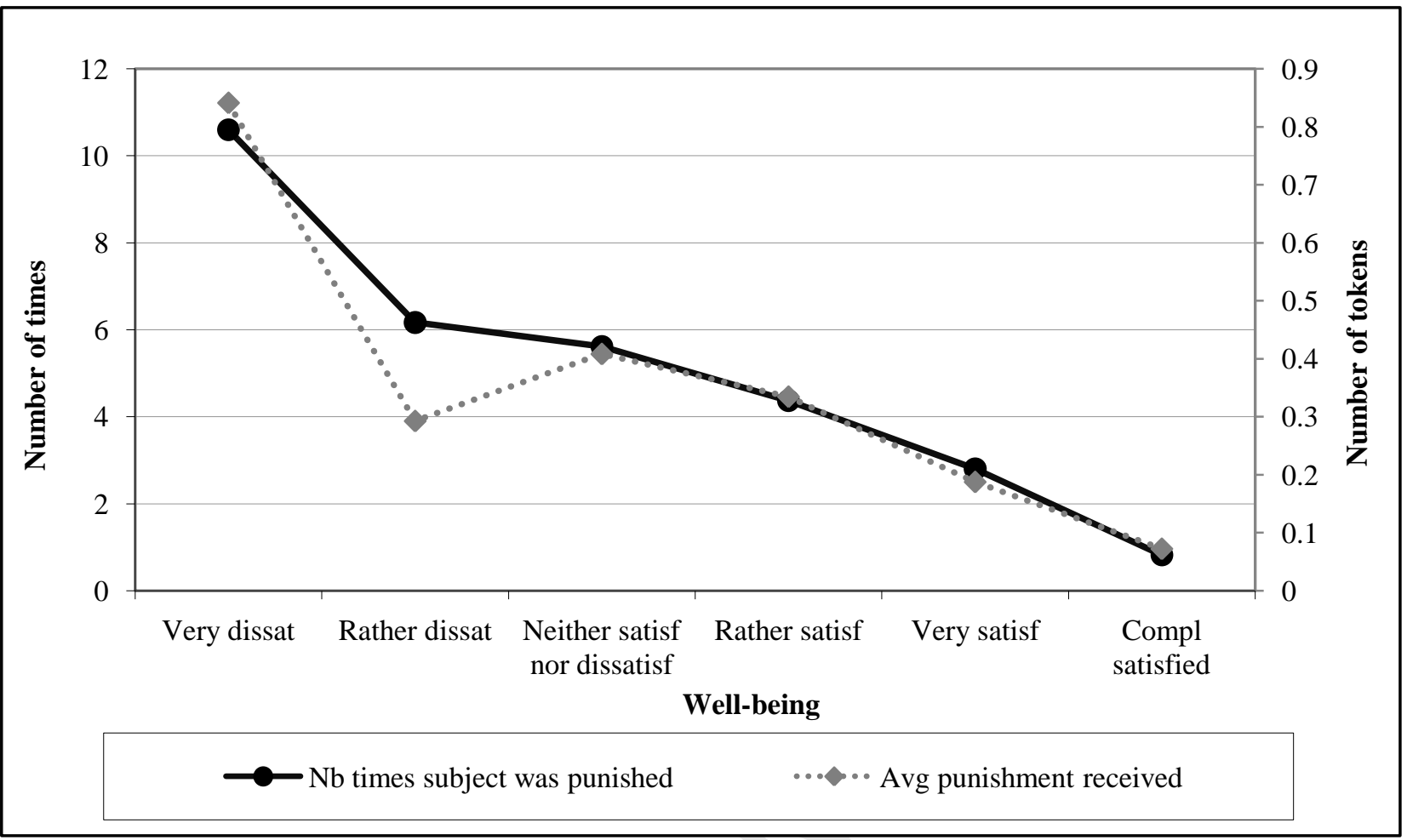


Table 1: Treatments and number of participants

\begin{tabular}{|c|c|c|c|c|c|}
\hline & & \multicolumn{3}{|c|}{ Type of punishment } & \multirow[t]{2}{*}{ Total } \\
\hline \multirow{3}{*}{ Type of matching } & \multirow{3}{*}{$\begin{array}{l}\text { Strangers } \\
\text { Partners }\end{array}$} & Strong & Soft & No Punishment & \\
\hline & & 22 & 22 & 20 & 64 \\
\hline & & 24 & 26 & 20 & 70 \\
\hline \multicolumn{2}{|c|}{ Total } & 46 & 48 & 40 & 134 \\
\hline
\end{tabular}


Table 2: Payoffs for the public good game

\begin{tabular}{clrlrrrr}
\hline $\mathrm{X} \backslash \mathrm{Y}$ & \multicolumn{1}{c}{0} & \multicolumn{1}{c}{1} & \multicolumn{1}{c}{2} & 3 & \multicolumn{1}{c}{4} & \multicolumn{1}{c}{5} \\
\hline 0 & 5,5 & $5.75,4.75$ & $6.5,4.5$ & $7.25,4.25$ & 8,4 & $8.75,3.8$ \\
1 & $4.8,5.75$ & $5.5,5.5$ & $6.25,5.25$ & 7,5 & $7.75,4.75$ & $8.5,4.5$ \\
2 & $4.5,6.5$ & $5.25,6.25$ & 6,6 & $6.75,5.75$ & $7.5,5.5$ & $8.25,5.3$ \\
3 & $4.3,7.25$ & 5,7 & $5.75,6.75$ & $6.5,6.5$ & $7.25,6.25$ & 8,6 \\
4 & 4,8 & $4.75,7.75$ & $5.5,7.5$ & $6.25,7.25$ & 7,7 & $7.75,6.8$ \\
5 & $3.8,8.75$ & $4.5,8.5$ & $5.25,8.25$ & 6,8 & $6.75,7.75$ & $7.5,7.5$ \\
\hline
\end{tabular}


Table 3: Punishment costs schedules

Strong Punishment Treatment

Deducted tokens

Cost to the punishing subject

$\begin{array}{lll}\mathbf{0} & \mathbf{0 . 5 0} & \mathbf{1 . 0 0}\end{array}$

$\begin{array}{llllll}\mathbf{0} & \mathbf{0 . 5 0} & \mathbf{1 . 0 0} & \mathbf{1 . 5 0} & \mathbf{2 . 0 0} & \mathbf{2 . 5}\end{array}$

$\mathbf{2 . 5 0} \quad 3.00$

0003.50

4.00

\begin{tabular}{llll}
4.50 & 5.00 & 5.50 & 6.00 \\
\hline
\end{tabular}

Punishment level

0

1

\section{Soft Punishment Treatment}

\begin{tabular}{lccccccccccccc}
\hline Deducted tokens & $\mathbf{0}$ & $\mathbf{0 . 2 0}$ & $\mathbf{0 . 4 0}$ & $\mathbf{0 . 6 0}$ & $\mathbf{0 . 8 0}$ & $\mathbf{1 . 0 0}$ & $\mathbf{1 . 2 0}$ & $\mathbf{1 . 4 0}$ & $\mathbf{1 . 6 0}$ & $\mathbf{1 . 8 0}$ & $\mathbf{2 . 0 0}$ & $\mathbf{2 . 2 0}$ & $\mathbf{2 . 4 0}$ \\
\hline Cost to the punishing subject & 0.00 & 0.125 & 0.250 & 0.375 & 0.500 & 0.625 & 0.750 & 0.875 & 1.000 & 1.125 & 1.250 & 1.375 & 1.500 \\
Punishment level & 0 & 1 & 2 & 3 & 4 & 5 & 6 & 7 & 8 & 9 & 10 & 11 & 12 \\
\hline
\end{tabular}


Table 4: Average values of the main variables

\begin{tabular}{|c|c|c|c|c|c|c|}
\hline & & & \multicolumn{3}{|c|}{ Type of Punishment } & \multirow{2}{*}{ Total } \\
\hline & & & Soft & Strong & No Punishment & \\
\hline \multirow{6}{*}{ Type of Matching } & \multirow{3}{*}{ Strangers } & Contribution to group account $* * *$ & 1.14 & 1.32 & 0.98 & 1.15 \\
\hline & & Punishment applied $* * *$ & 0.09 & 0.60 & ------- & 0.24 \\
\hline & & Final earnings $* * *$ & 5.42 & 4.91 & 5.49 & 5.26 \\
\hline & \multirow{3}{*}{ Partners } & Contribution to group account $* * *$ & 2.73 & 3.08 & 2.65 & 2.83 \\
\hline & & Punishment applied $* *$ & 0.30 & 0.33 & ------- & 0.22 \\
\hline & & Final earnings $* * *$ & 5.88 & 6.13 & 6.33 & 6.09 \\
\hline \multirow{3}{*}{\multicolumn{2}{|c|}{ Total }} & Contribution to group account $* * *$ & 2.00 & 2.24 & 1.81 & 2.03 \\
\hline & & Punishment applied $* *$ & 0.20 & 0.46 & ------- & 0.23 \\
\hline & & Final earnings $* *$ & 5.67 & 5.54 & 5.91 & 5.70 \\
\hline
\end{tabular}

Krustal-Wallis test $\quad * * * \mathrm{p}$-value $<0.01$

$* *$ p-value $<0.05$ 
Table 5: Estimations of the punishment behavior

Probit estimation $\quad$ Marginal effects Robust Std-Error

\begin{tabular}{lccc}
\hline & $(\mathrm{I})$ & $(\mathrm{II})$ & $(\mathrm{III})$ \\
\hline Strong Punishment & $0.1372 * *$ & $0.1530^{* * *}$ & $0.1530^{* * *}$ \\
& 0.06 & 0.06 & 0.06 \\
Partners Matching & 0.0623 & $0.1263^{*}$ & $0.1262^{*}$ \\
& 0.07 & 0.07 & 0.07 \\
Negative deviation & & $0.1834 * * *$ & $0.1830^{* * *}$ \\
& & 0.03 & 0.03 \\
Positive deviation & & $0.0331^{*}$ & $0.0327 *$ \\
& & 0.02 & 0.02 \\
Period & & & -0.0005 \\
& & & 0.00 \\
\hline Nb of observations & 1880 & 1880 & 1880 \\
Prob > chi2 & 0.0174 & 0.0000 & 0.0000 \\
\hline
\end{tabular}

*** significant at 1 percent level

** significant at 5 percent level

* significant at 10 percent level 
Table 6: Average final earnings (in euros)

\begin{tabular}{rlcccc}
\hline & & \multicolumn{3}{c}{ Type of Punishment } & \multirow{2}{*}{ Total } \\
\cline { 2 - 5 } & & Soft & Strong & No Punishment & \\
\hline \multirow{2}{*}{ Type of Matching } & Strangers & 10.84 & 9.82 & 10.98 & 10.53 \\
& Partners & 11.76 & 12.25 & 12.65 & 12.18 \\
\hline Total & & 11.34 & 11.09 & 11.81 & 11.39 \\
\hline
\end{tabular}


Table 7: Results of the ordered probit estimation

\begin{tabular}{|c|c|c|c|c|c|c|}
\hline \multirow[t]{2}{*}{ Ordered probit estimation } & \multicolumn{2}{|r|}{ Coefficient } & \multicolumn{2}{|c|}{ Std-Error } & \multirow[b]{2}{*}{ (V) } & \multirow[b]{2}{*}{ (VI) } \\
\hline & (I) & (II) & (III) & $(\mathrm{IV})$ & & \\
\hline \multirow[t]{2}{*}{ Strong Punishment } & 0.1767 & 0.1701 & $0.6093^{* * *}$ & $0.6864 * * *$ & $0.9461 * * *$ & $0.8229 * * *$ \\
\hline & 0.22 & 0.23 & 0.24 & 0.24 & 0.28 & 0.29 \\
\hline \multirow[t]{2}{*}{ Soft Punishment } & -0.2007 & -0.2387 & -0.0461 & -0.0567 & 0.1260 & -0.0048 \\
\hline & 0.22 & 0.22 & 0.23 & 0.23 & 0.25 & 0.26 \\
\hline \multirow[t]{2}{*}{ Partners Matching } & & $0.6665^{* * *}$ & 0.0462 & -0.0324 & 0.0659 & -0.0495 \\
\hline & & 0.00 & 0.24 & 0.25 & 0.26 & 0.27 \\
\hline \multirow[t]{2}{*}{ Final Earnings } & & & $0.4964 * * *$ & $0.4267 * * *$ & $0.3419 * * *$ & $0.3971 * * *$ \\
\hline & & & 0.07 & 0.07 & 0.08 & 0.09 \\
\hline \multirow[t]{2}{*}{$\mathrm{Nb}$ times subject contrib more than partner } & & & & $-0.0898 * * *$ & $-0.1052 * * *$ & $-0.1199 * * *$ \\
\hline & & & & 0.03 & 0.03 & 0.03 \\
\hline \multirow[t]{2}{*}{$\mathrm{Nb}$ times subject was punished } & & & & & $-0.0560^{*}$ & $-0.0799 * *$ \\
\hline & & & & & 0.03 & 0.03 \\
\hline \multirow[t]{2}{*}{$\mathrm{Nb}$ times subject punished the partner } & & & & & & $0.0606 * *$ \\
\hline & & & & & & 0.03 \\
\hline Number of observations & 134 & 134 & 134 & 134 & 134 & 134 \\
\hline Prob $>$ chi 2 & 0.2131 & 0.0010 & 0.0000 & 0.0000 & 0.0000 & 0.0000 \\
\hline
\end{tabular}

* significant at 10 percent level

** significant at 5 percent level

*** significant at 1 percent level 
Table 8: Marginal effects of the ordered probit model

\begin{tabular}{lcccccc}
\hline & $\begin{array}{c}\text { Very } \\
\text { dissatisfied }\end{array}$ & $\begin{array}{c}\text { Rather } \\
\text { dissatisfied }\end{array}$ & $\begin{array}{c}\text { Neither } \\
\text { dissatisfied/ } \\
\text { Satisfied }\end{array}$ & $\begin{array}{c}\text { Rather } \\
\text { satisfied }\end{array}$ & $\begin{array}{c}\text { Very } \\
\text { satisfied }\end{array}$ & $\begin{array}{c}\text { Completely } \\
\text { satisfied }\end{array}$ \\
\hline \multicolumn{1}{c}{ Variables } & $\mathbf{P}(\mathbf{W B}=\mathbf{2})$ & $\mathbf{P}(\mathbf{W B}=\mathbf{3})$ & $\mathbf{P}(\mathbf{W B}=\mathbf{4})$ & $\mathbf{P}(\mathbf{W B}=\mathbf{5})$ & $\mathbf{P}(\mathbf{W B}=\mathbf{6})$ & $\mathbf{P}(\mathbf{W B}=\mathbf{7})$ \\
\hline Strong Punishment & $-0.0254^{*}$ & $-0.0947^{* *}$ & $-0.1773^{* *}$ & $0.0848^{* *}$ & $0.1359^{* *}$ & $0.0766^{*}$ \\
Soft Punishment & 0.0002 & 0.0006 & 0.0010 & -0.0008 & -0.0008 & -0.0003 \\
Partners Matching & 0.0018 & 0.0066 & 0.0107 & -0.0078 & -0.0078 & -0.0035 \\
Final Earnings & $-0.0146^{* *}$ & $-0.0527^{* * *}$ & $-0.0860^{* * *}$ & $0.0626^{* *}$ & $0.0629^{* *}$ & $0.0278^{* * *}$ \\
Nb times subject contrib more than partner & $0.0044^{* *}$ & $0.0159^{* * *}$ & $0.0259^{* *}$ & $-0.0189^{* *:}$ & $-0.0190^{* *}$ & $-0.0084^{*}$ \\
Nb times subject was punished & $0.0029^{*}$ & $0.0106^{* *}$ & $0.0173^{* *}$ & $-0.0126^{* *}$ & $-0.0127^{* *}$ & $-0.0056^{*}$ \\
Nb times subject punished the partner & -0.0022 & $-0.0080^{* *}$ & $-0.0131^{* *}$ & $0.0096^{*}$ & $0.0096^{* *}$ & $0.0042^{*}$ \\
\hline
\end{tabular}

*** significant at 1 percent level

** significant at 5 percent level

* significant at 10 percent level 
Table A1: Earnings depending on contributions (X $\backslash \mathrm{Y})$ to account A

\begin{tabular}{crrrrrrr}
\hline $\mathrm{X} \backslash \mathrm{Y}$ & 0 & 1 & 2 & 3 & \multicolumn{1}{c}{4} & 5 \\
\hline 0 & 5,5 & $5.75,4.75$ & $6.5,4.5$ & $7.25,4.25$ & 8,4 & $8.75,3.75$ \\
1 & $4.75,5.75$ & $5.5,5.5$ & $6.25,5.25$ & 7,5 & $7.75,4.75$ & $8.5,4.5$ \\
2 & $4.5,6.5$ & $5.25,6.25$ & 6,6 & $6.75,5.75$ & $7.5,5.5$ & $8.25,5.25$ \\
3 & $4.25,7.25$ & 5,7 & $5.75,6.75$ & $6.5,6.5$ & $7.25,6.25$ & 8,6 \\
4 & 4,8 & $4.75,7.75$ & $5.5,7.5$ & $6.25,7.25$ & 7,7 & $7.75,6.75$ \\
5 & $3.75,8.75$ & $4.5,8.5$ & $5.25,8.25$ & 6,8 & $6.75,7.75$ & $7.5,7.5$ \\
\hline
\end{tabular}


Table A2

Deducted tokens

\begin{tabular}{lllllllllllll}
$\mathbf{0}$ & $\mathbf{0 . 5 0}$ & $\mathbf{1 . 0 0}$ & $\mathbf{1 . 5 0}$ & $\mathbf{2 . 0 0}$ & $\mathbf{2 . 5 0}$ & $\mathbf{3 . 0 0}$ & $\mathbf{3 . 5 0}$ & $\mathbf{4 . 0 0}$ & $\mathbf{4 . 5 0}$ & $\mathbf{5 . 0 0}$ & $\mathbf{5 . 5 0}$ & $\mathbf{6 . 0 0}$ \\
\hline
\end{tabular}

\begin{tabular}{lllllllllllllll}
\hline Cost to the punishing subject & 0.00 & 0.125 & 0.250 & 0.375 & 0.500 & 0.625 & 0.750 & 0.875 & 1.000 & 1.125 & 1.250 & 1.375 & 1.500 \\
\hline
\end{tabular} 
Table A3

\begin{tabular}{|c|c|c|c|c|}
\hline $\begin{array}{c}\text { Very much } \\
\text { agree }\end{array}$ & Agree & $\begin{array}{c}\text { Neither agree } \\
\text { nor disagree }\end{array}$ & Disagree & $\begin{array}{c}\text { Very much } \\
\text { disagree }\end{array}$ \\
\hline & & & & \\
\hline
\end{tabular}




\title{
On Punishment and Well-being
}

\author{
Jordi Brandts*and María Fernanda Rivas ${ }^{\ddagger}$
}

July 30, 2009

\begin{abstract}
The existence of punishment opportunities has been shown to cause efficiency in some public goods experiments to increase considerably. In this paper we ask whether punishment also has a downside in terms of process dissatisfaction. We conduct an experiment to study the conjecture that an environment with strong punishment possibilities may lead to higher material payoffs but lower subjective well-being, in comparison with weaker punishment or no punishment possibilities at all. The more general motivation for our study stems from the notion that people's subjective well-being may be affected by the institutional environment they find themselves in. Our findings show that harsher punishment possibilities lead to significantly higher well-being, controlling for earnings and other relevant variables. These results complement the evidence on the neural basis of altruistic punishment reported in de Quervain et al. (2004).
\end{abstract}

JEL Classification Numbers: C92, D60, H40

Keywords: Public Goods, Experiments, Well-being, Punishment

\footnotetext{
${ }^{*}$ Department of Business Economics, Universitat Autònoma de Barcelona and Institut d'Anàlisi Econòmica (CSIC), Barcelona.

${ }^{\dagger}$ GLOBE, Department of Economics, Universidad de Granada.

${ }^{\ddagger}$ The authors thank the Spanish Ministry of Science and Innovation, the Barcelona GSE Research Network and Consolider-Ingenio 2010 (CSD2006-00016) for financial support.
} 